\title{
EXPLAINING THE RELATIONSHIP BETWEEN PUBLIC EXPENDITURE AND ECONOMIC GROWTH IN KENYA USING VECTOR ERROR CORRECTION MODEL (VECM)
}

\author{
CHRISTINE NANJALA SIMIYU
}

\begin{abstract}
:
The rapid growth in public expenditure in Kenya since independence has caused concern among policy makers on its implication on economic growth. The main aim of this study therefore was to explain the relationship between economic growth and public expenditure on Health, Education, Military and Infrastructure in Kenya. The study used a time series data collected between 1963 2012. Johansen Cointegration Test and Vector Error Correction Model (VECM) was applied on the time series data to estimate the short-run and long-run relationships between public expenditures and economic growth in Kenya. The results suggests that public expenditure components and economic growth co-move towards a long run equilibrium with a speed of adjustments of approximately $3.6 \%$ after short run fluctuations in the equilibrium. Furthermore, the results show no casual relationship between public expenditure and economic growth in Kenya. However, there exist a unidirectional causation between Military and Health expenditures - Military expenditures "Granger Cause" Health expenditures. Hence, a change in Military expenditures cause a change in Health expenditures. These findings suggests that the Government of Kenya switch military expenditures for health expenses in Kenya, but not vice versa.
\end{abstract}

\section{Keywords:}

Vector Error Correction Model (VECM), Granger Causation, Public expenditures Components, Economic Growth, Kenya

JEL Classification: H50, O47, C32

\section{Authors:}

CHRISTINE NANJALA SIMIYU, KCA University, Kenya, Email: csimiyu@kca.ac.ke

\section{Citation:}

CHRISTINE NANJALA SIMIYU (2015). Explaining the Relationship between Public Expenditure and Economic Growth in Kenya using Vector Error Correction Model (VECM). International Journal of Economic Sciences, Vol. IV(3), pp. 19-38., 10.20472/ES.2015.4.3.002 


\subsection{Introduction}

The relationship between public expenditure components (Health, Education, Military and Infrastructure) and economic growth is a critical subject of analysis for development economists as the two are interrelated (Stiglitz, 2000). Several empirical studies which have been done in this area has generated different results. On one hand, government expenditure has been seen as a key booster of productivity in the economy hence encouraging economic growth. For instance, public expenditures on health and education are likely to increase the level of human capital and capacity which will impact positively on the physical capital accumulation in the economy hence increase in the economic growth. Furthermore, Barro \& Sala (1992) suggest that public expenditure on infrastructure has direct effects - a change in public expenditure on infrastructure directly affects the growth of the economy. On the other hand, public expenditure has been seen as an impediment to development (or economic growth) because of the debts incurred by the government to finance the expenditures ${ }^{1}$, hence the differences in the findings of the studies done.

According to Eastely (2003) studies done on this contentious topic have their merits. In most cases however, these subjects suffer from the differences in the fundamental data sets, estimation techniques, time periods and different variable measurement which can yield different results. Some studies conclude that increased public expenditures have a positive effect on economic growth (Singh \& Sahni, 1984; Ram, 1986; and Holmes \& Hutton, 1990) while others suggest a negative effect of public expenditures on economic growth (Landau, 1986). Ram (1996) examined the public expenditure of 63 developed and developing countries but detects no consistent casual pattern between public expenditures and economic growth.

Noteworthy, Jerono (2009) states that studies done in Kenya on the relationship between public expenditure and economic growth have reported different and contradicting results. Some studies suggest that increased public expenditures are growth enhancing, other studies reports that increased public expenditures is growth impending while others report that increased public expenditures cannot predict economic growth in Kenya. For instance, Munge (2005) investigated a casual relationship between public expenditure and economic growth in Kenya by examining the public share of expenditure on Gross Domestic Product (GDP). The study finds that there is no casual relationship between the share of public expenditure and economic growth in Kenya. The analysis further finds no evidence that public expenditures has effect on economic growth. Recently, Muthui et al (2013) studied the impact of public expenditure components on economic growth in Kenya. They conclude, from their study, that the composition of government expenditure matter for economic growth.

Majority of the empirical analysis of the effect of public expenditure on long-run economic growth use cross-sectional analysis using regression model which does not capture the dynamics of the associations between economic growth and public expenditures in the long run. In order to incorporate dynamism in the analysis time series data is

\footnotetext{
1 By borrowing to finance public expenditure the government compete with private investors for capital thereby crowding out private investment hence enhancing enormous foreign debtburden (World Bank, 1991)
} 
recommended by Shioji (2001). Hence, Maingi (2010) and Muthui et al., (2013) studied the effect of public expenditure on economic growth using time series data and analysis in Kenya. However, these studies did not focus on the analysis of the relationship between public expenditure components and economic growth using econometric models such as Vector Error Corrections (VECM) model to estimate the short run and long run relationship between the public expenditure and economic growth in Kenya. This paper therefore, endeavors to use VECM to explain the relationship between public expenditure components and economic growth in Kenya. The VECM model is applied on a time series data collected between 1963 - 2012 in Kenya.

The results from this study shows that the public expenditure components in Health, Education, Military and Infrastructure have a long run relationship with economic growth. The results suggest that when there are short run fluctuations in the equilibrium the variables adjust at a speed of $3.6 \%$ towards a long run equilibrium. Further the results shows that there is no casual relationship between public expenditure and economic growth. The balance of the paper proceed as follows: section 2 explain the methodology used in the paper; section 3 presents the results from the analysis; and section 4 concludes with policy implications.

\subsection{Methodology}

\subsection{Model Specification}

The theoretical model is identified to be of the form:

$$
\text { GDP GROWTH }=f(\text { Public Expenditure Components })
$$

where;

$$
\begin{aligned}
& \text { GDP GROWTH }=\frac{\text { GDP per Capita } a_{t} \text { GDP per Capita }}{t-1} \\
& \text { aDP per Capita } \\
& \text { and } \\
& \text { GDP per Capita }=\frac{G D P_{t}}{\text { POPULATION }_{t}}
\end{aligned}
$$

The public expenditure components which include: Health, Education, Military and Infrastructure expenditures are in million Kenya shillings per year. The proportion of the expenditure share to the total GDP for each expenditure component was calculated as:

$$
\text { Expenditure } \text { Share }_{t}=\frac{\text { Expenditure }_{t}}{G D P_{t}}
$$

Hence the theoretical model is modified to be of the form:

$$
\text { GDP GROWTH }=f\left(\text { Expenditure Share }_{t}\right)
$$

Time series yearly data was used in the study for the periods between $1963-2012$. The data was obtained from World Bank, Ministry of Planning and the National Development and Vision 2030 publications. Data on public expenditures components was classified under each functional and economic activity. 


\subsection{Time series analysis}

The study used time series econometric models in establishing the relationship between GDP growth ${ }^{2}$ and Public expenditure components - as a share of GDP. The linearity relationship is assumed between variables for the model specified ${ }^{3}$ in section 2.1 above. To address the objective of the study, the data was analyzed step by step using the processes and methods as described in the proceeding sections.

\subsubsection{Stationarity Test.}

Stationarity of a series is important due to influence it has on its behaviour. Thus, if $X$ and $Y$ series are non-stationary processes, then modeling $X$ and $Y$ relationship as a simple linear regression as in equation (6) shown below will lead to spurious ${ }^{4}$ regression (Asari et al, 2011).

$$
Y_{t}=\beta_{0}+\beta_{1} X_{t}+\varepsilon_{t}
$$

Time series data is said to be stationary if its mean, variance and covariances do not vary overtime. Non-stationary data leads to spurious regression due to non-constant mean and variance (Dimitrova, 2005). Differencing a series using differencing operators produces other set of observations. For instance, the first-differenced values are given as: $\Delta X_{t}=X_{t}-X_{t-1}$. If a series is stationary without any differencing, it is said to be $\mathrm{l}(0)$ or integrated of order 0 . However, if a series is stationary after first-difference is said to be I(1) or integrated of order 1. In order to check for stationarity in the series (whether in levels or first-differences), the Dickey and Fuller (1979) test was used.

\subsubsection{Cointegration test}

After establishing whether the series is stationary in levels or first-difference (and if the series are integrated of the same order), then Johansen's procedure is used to determine whether there exist a cointegrating vector among the variables (Johansen, 1988).

The procedure uses two tests to determine the number of cointegrating vectors which are: the Maximum Eigenvalue test and the Trace test. The null hypothesis for the Maximum Eigenvalue is to test $r$ cointegrating relations against the alternative of $r+1$ cointegrating relations where $r=0,1,2, \ldots, n-1$ and $n$ is the number of variables in the system. The test statistic for Maximum Eigenvalue is computed as:

$$
L R_{\text {max }}(r / n+1)=-T * \log (1-\widehat{\omega})
$$

where $\omega$ is the Maximum Eigenvalue and $\mathrm{T}$ is the sample size.

The Trace statistics tests the null hypothesis of $r$ cointegrating relations against the alternative of $n$ cointegrating relations, where $n$ is the number of variables in the system and $r=0,1,2, \ldots, n-1$. The test statistic is computed using the following expression:

\footnotetext{
${ }^{2}$ GDP growth, in this study, will be used interchangeably with economic growth

${ }^{3}$ The linearity as sumption is appropriate because the Government of Kenya applies the additive principle in allocating its expenditure to various sectors such that each expenditure item has independent contribution to GDP growth.

${ }^{4}$ Spurious regression is where the test statis tics exhibit a significant relationship between variables even when no such relationship exists.
} 


$$
L R_{t r}(r / n)=-T * \sum_{i=r+1}^{n} \log \left(1-\widehat{\omega_{l}}\right)
$$

In some cases the Maximum Eigenvalue statistic and the Trace statistic may yield different results. In the event that this happens, Alexander (2001) indicates the results of trace test should be preferred.

Before the Johansen cointegration test is performed, the optimal lag length for analysis should be identified. The lag length is selected using the information selection criteria which include: Sequential Modified Likelihood Ratio (LR), Final Prediction Error (FPE), Akaike Information Criterion (AIC), Schwarz Bayesian Information Criterion (SBIC) and Hannan-Quinn Information Criterion (HQIC) and ensuring that the residuals are white noise as suggested by kanov et al (2005).

\subsubsection{Vector Error Correction Model (VECM)}

After the Johansen cointegration test is performed, next is to fit the appropriate time series model. If cointegration has been established between the variables, then this implies that there exist a long run relationship between variables. Hence, the VECM is applied in order to determine the short run relationships of cointegrated variables. On the other hand, if there exist no cointegration, then the VECM is reduced to Vector autoregressive (VAR) model, and the Granger Casuality tests will be used to determine casual links between variables. The regression equation form for VECM is given as:

$$
\begin{aligned}
& \Delta \text { GDPgrowth }_{t}=\alpha_{1}+\alpha_{1} e_{t-1}+\sum_{i=0}^{n} \beta_{i} \Delta \text { GDPgrowth }_{t-i}+\sum_{i=0}^{n} \delta_{i} \Delta \text { ExpShareX }_{t-i} \\
& \Delta \text { ExpShare }_{t}=\alpha_{1}+\alpha_{1} e_{t-1}+\sum_{i=0}^{n} \beta_{i} \Delta \text { ExpShare }_{t-i}+\sum_{i=0}^{n} \delta_{i} \Delta \text { GDP growth }_{t-i}
\end{aligned}
$$

In the VECM modeling above, the cointegration rank shows the number of cointegrating vectors. For example, rank of four indicates that four linearly independent combinations of the non-stationary variables will be stationary. The Error Correction Component (ECM) - given as the coefficient of $e_{t-1}$ shows the speed of adjustment of the variables towards a long run equilibrium after short run fluctuations of the variables.

\subsubsection{Granger Casuality Test}

The Granger Casuality test determines the casual relationship between GDP growth and public expenditure components. The Granger method sought to explain how much of a variable $X$ (public expenditure components) can be explained by its own past values and whether adding lagged values of another variable $Y$ (GDP growth) can explain better. It involves estimation of the following equations:

$$
\begin{aligned}
& Y_{t}=\alpha_{0}+\sum_{i=1}^{n} \alpha_{i} Y_{t-i}+\sum_{j=1}^{n} \beta_{j} X_{t-j}+\varepsilon_{1} \\
& X_{t}=\alpha_{0}+\sum_{i=1}^{m} \lambda_{i} Y_{t-i}+\sum_{j=1}^{m} \delta_{j} X_{t-j}+\varepsilon_{2}
\end{aligned}
$$

In the model, "t" denotes time periods and $\varepsilon$ is a white noise error term. The constant parameter $\alpha_{0}$ denotes constant growth rate of $Y$ in equation (8) and for $X$ in equation (9). The trend is interpreted as general movements of cointegration between $X$ and $Y$ that follows the unit root process. The null hypothesis for equation (8) is: $H_{0}: \beta_{j}=0$, which implies that there is no causation from $Y$ to $X$ or $Y$ does not Granger Cause $X$. The null 
hypothesis for equation (11) is: $H_{0}: \delta_{j}=0$, implying that there is no causation from $\mathrm{X}$ to $\mathrm{Y}$ or $\mathrm{X}$ does not Granger Cause $\mathrm{Y}$. The presence of both unilateral and bilateral casuality should be analyzed. Unilateral casuality will occur between variables if either null hypothesis of equation (8) or (9) is rejected, while bilateral casuality will occur between variables if both null hypothesis are rejected. No casuality exists if neither null hypothesis of equation (8) nor (9) are rejected (Duasa, 2007).

\subsection{Results}

In this section, the preliminary analysis of the data is performed to check whether the data is stationary. The time series plots, correlogram plots and the Augmented Dickey Fuller (ADF) test is used to check for stationarity of variables in the dataset. In addition, the Johansen Cointergartion test will be performed to determine the appropriate time series model to fit. Further, the results of VECM are specified and interpreted.

\subsection{Testing for stationarity}

Time series plots usually give the simplest method for checking stationarity of the variables in the dataset. Figure 1, in the Appendix, presents the results for time series plots. The output suggests possible non-stationarity of the variables (apart from GDP growth) since their movements overtime exhibit a trend. The correlograms in Figure 2 in the Appendix further suggests non-stationarity of the variables since they decay slowly suggesting that there exist a trend overtime in the variables. To empirically confirm that the variables are non-stationary, Augmented Dickey Fuller (ADF) unit root test was performed. The results in Table 1 indicates that (apart from GDP Growth) all the variables are non-stationary in levels.

These findings shows that the first difference of the variables has to performed to achieve stationarity of the variables. Table 2 presents the results of ADF unit root test for first difference of the variables (without trend). The results shows that all variables are stationary after first difference implying that the variables are integrated to order one I(1). The time series plots and correlograms of the variables after first difference of the data are shown in figure 3 and figure 4 respectively, in the Appendix, which also points at stationarity of the variables. The time series plots do not exhibit any trend and the correlograms do not die away slowly indicating that the first difference variables are stationary.

Table 1: ADF Unit Root Test for Variables in Levels

\begin{tabular}{|l|c|c|c|c|c|}
\hline \multirow{2}{*}{ Variable } & \multirow{2}{*}{ Test Statistic } & \multicolumn{3}{|c|}{- -------Interpolated Dickey-Fuller-------- } & \multirow{2}{*}{ p-value } \\
\cline { 3 - 5 } & & $\begin{array}{c}1 \% \text { Critical } \\
\text { Value }\end{array}$ & $\begin{array}{c}5 \% \text { Critical } \\
\text { Value }\end{array}$ & $\begin{array}{c}10 \% \text { Critical } \\
\text { Value }\end{array}$ & \\
\hline Health & & & & & \\
\hline No trend & -3.079 & -3.587 & -2.933 & -2.601 & 0.0282 \\
\hline
\end{tabular}




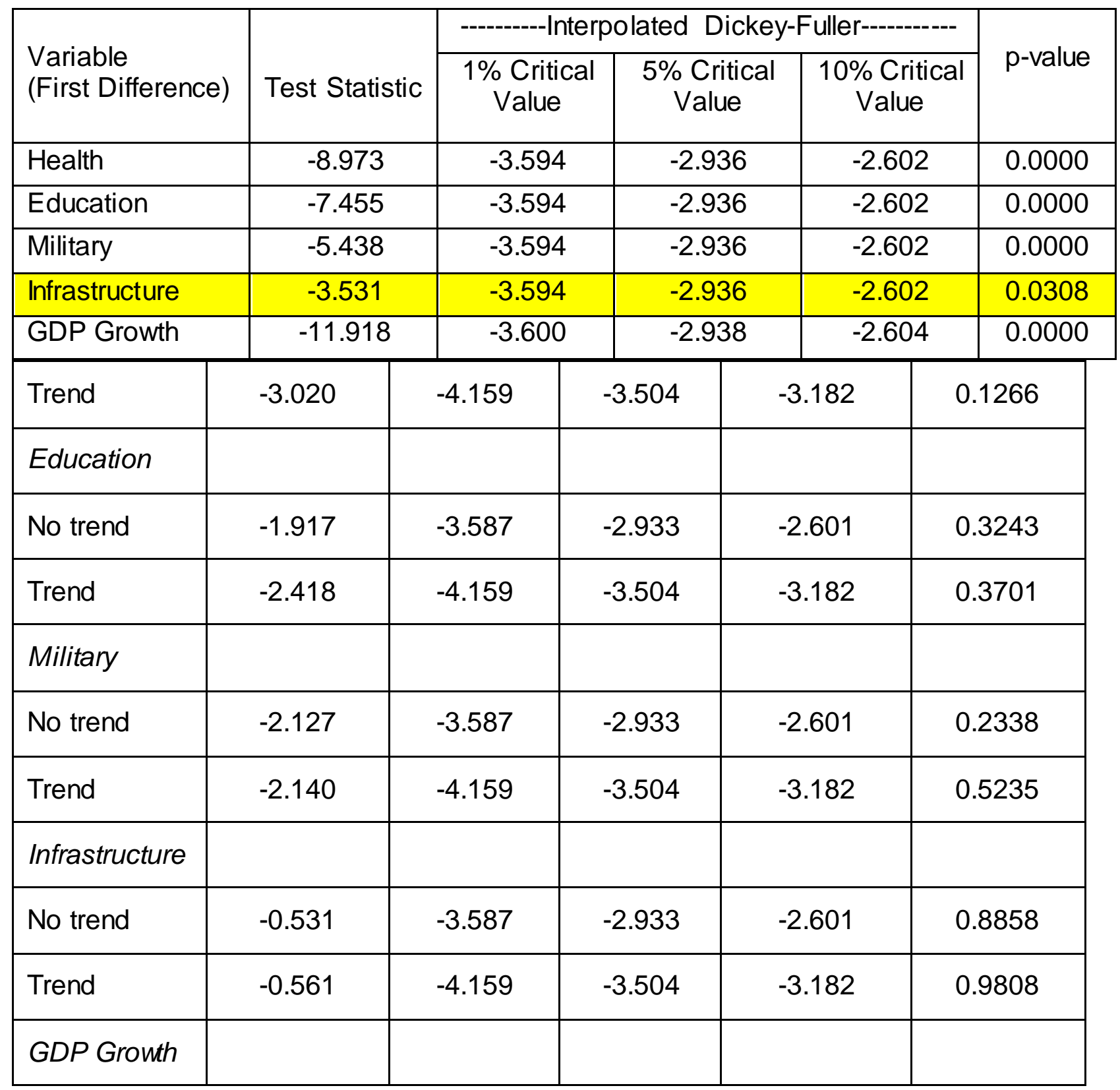

Source : Research Data(2015)

Table 2: ADF Unit Root Test for First Difference (No Trend)

\begin{tabular}{|l|l|l|l|l|l|}
\hline No trend & -5.051 & -3.587 & -2.933 & -2.601 & 0.0000 \\
\hline Trend & -5.009 & -4.159 & -3.504 & -3.182 & 0.0002 \\
\hline
\end{tabular}

Source : Research Data(2015)

Having established that the variables are I(1), the next step of analysis is fitting time series models to the data set. 


\subsection{Vector Autoregressive and Vector Error Correction Models.}

In section 3.1 above, the results shows that the variables are I(1) implying that either Vector Autoregressive (VAR) model or Vector Error Correction Model (VECM) can be fit to the first difference of the variables in the time series dataset. In order to choose the appropriate model, the paper need to establish if the time series is cointegrated. If there exist cointegration in the series then fitting the VAR model to the first difference of the variables may lead to misspecification of the model. Hence, the VECM will be appropriate which captures both the short run and long run relationship between the variables.

To start with, in this section, the paper determines whether cointegration exist among the variables using Johansen Cointegration Test. If the series is cointegrated, then the VECM will be used to determine the short run and long run casuality between the variables. However, if there is no cointegration in the series then the VECM is reduced to VAR model. Before determining whether there exist cointegration, the first step is to select the optimal lag length. Next, is to identify the cointegrating rank before specifying the model and testing the adequacy of the model.

\subsubsection{Lag length selection}

The first step in the time series analysis is to select an appropriate lag length which ensures that the model is not mispecified (Enders, 1995). In the literature, there are various methods used for optimal lag length selection which include: Sequential Modified Likelihood Ratio (LR), Final Prediction Error (FPE), Akaike Information Criterion (AIC), Schwarz Bayesian Information Criterion (SBIC) and Hannan-Quinn Information Criterion (HQIC). There is no clear thump of rule on which criterion to use for optimal lag length selection among the above methods. However, the decision rule is to choose the model with lowest value of information criteria. Table 3 presents the results for lag length selection using the above-mentioned criteria.

The lowest information criterion for LR is lag 3 whereas for FPE, AIC HQIC and SBIC is lag 1. Majority of the criteria point at lag 1 as the optimal lag for analysis. However, in the event of conflict in the lag length selection, the appropriate way is to plot correlogram of residuals and select a lag length as the one where the correlogram is statistically insignificant. The correlogram of the residuals is shown in Figure 1. From the output, the optimal lag length is identified to be lag 1.

After determination of the optimal lag length for analysis, the next step is to determine if the series are cointegrated. This is discussed in the proceeding section.

Table 3: Results of Lag length selection

\begin{tabular}{|c|c|c|c|c|c|c|c|c|}
\hline Lag & LL & LR & df & $p$ & FPE & AIC & HQIC & SBIC \\
\hline 0 & -304.227 & & & & .874972 & 14.0558 & 14.131 & 14.2585 \\
\hline
\end{tabular}




\begin{tabular}{|c|c|c|c|c|c|c|c|c|}
\hline 1 & -254.617 & 99.221 & 25 & 0.000 & $.288314^{*}$ & $12.9371^{*}$ & $13.3883^{*}$ & $14.1536^{*}$ \\
\hline 2 & -240.374 & 28.486 & 25 & 0.286 & .492053 & 13.4261 & 14.2532 & 15.6563 \\
\hline 3 & -220.876 & $38.995^{\star}$ & 25 & 0.037 & .712586 & 13.6762 & 14.8792 & 16.9202 \\
\hline 4 & -205.329 & 31.095 & 25 & 0.186 & 1.40243 & 14.1059 & 15.6848 & 18.3636 \\
\hline
\end{tabular}

Figure 1: Correlogram of Residuals for VAR Lag Selection

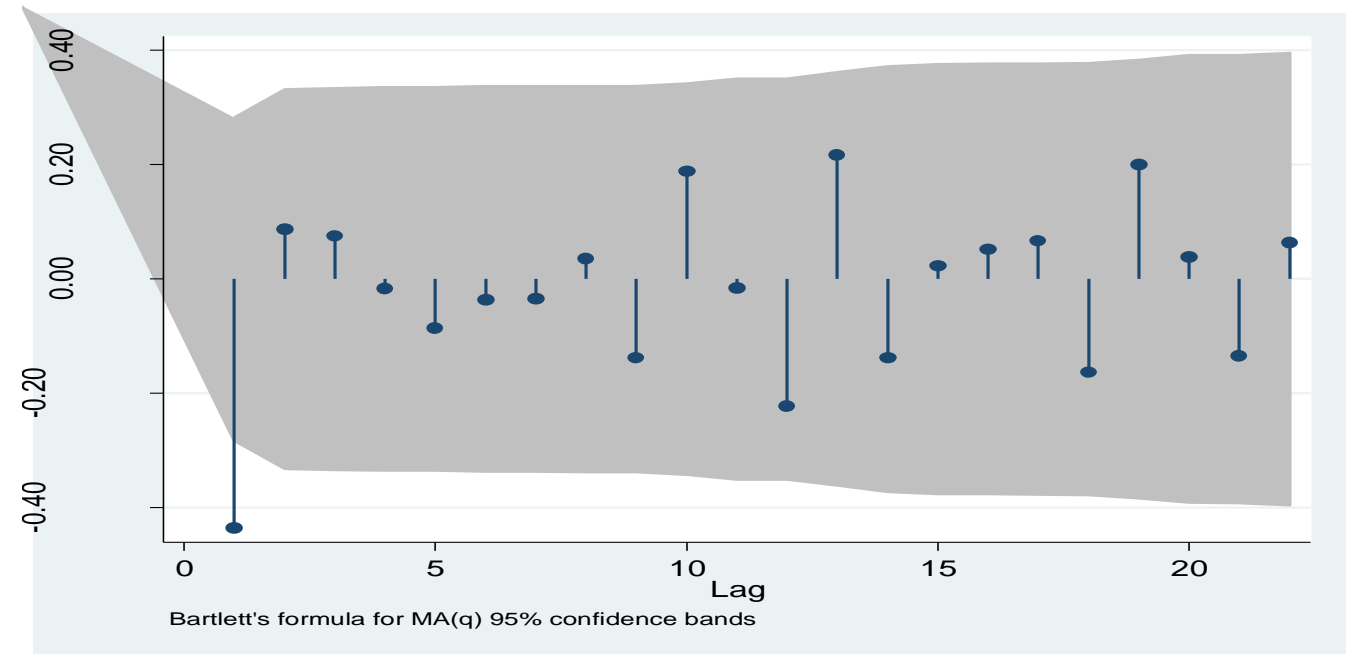

\subsubsection{Cointegration test}

In order to investigate the long run relationship between GDP growth and Public expenditures in Health, Education, Military and Infrastructure, the variables have to first be tested for cointegration. If the series are cointegrated, then the corresponding error correction term and an error correction model must be constructed. Johansen Cointegration Test is used to determine if the variables co-move towards a long run equilibrium. The results in Table 4 suggests that the variables are cointegarted with cointegration rank of order 4 . These findings indicate that the appropriate model to fit in the data is VECM.

Table 4: Johansen Cointegration Test

\begin{tabular}{|c|c|c|c|c|c|}
\hline $\begin{array}{c}\text { maximum } \\
\text { rank }\end{array}$ & parms & LL & eigenvalue & $\begin{array}{c}\text { trace } \\
\text { statistic }\end{array}$ & $\begin{array}{c}5 \% \text { critical } \\
\text { value }\end{array}$ \\
\hline 0 & 5 & -369.84138 & $\cdot$ & 199.2327 & 68.52 \\
\hline 1 & 14 & -325.37473 & 0.84926 & 110.2993 & 47.21 \\
\hline
\end{tabular}




\begin{tabular}{|l|l|l|l|l|l|}
\hline 2 & 21 & -297.5789 & 0.69358 & 54.7077 & 29.68 \\
\hline 3 & 26 & -281.4734 & 0.49608 & 22.4967 & 15.41 \\
\hline 4 & 29 & -270.4134 & 0.37540 & $0.3767^{*}$ & 3.76 \\
\hline 5 & 30 & -270.22505 & 0.00798 & & \\
\hline
\end{tabular}

\subsection{Vector Error Correction Model}

The presence of cointegration amongst variables suggests that the variables have a long run relationship, hence the VECM is appropriate for modeling the relationship between GDP growth and public expenditures in Health, Education, Military and Infrastructure. Further, the VECM also reports the short run relationship amongst variables and how they adjust towards a long run equilibrium.

From Table 5, the cointegrating equation between GDP growth and public expenditure components (Health, Education, Military and Infrastructure) for Kenya in the period of 1963 - 2012 is given as:

GDPGROWTH $=9.8102-204.014 \Delta H E A L T H+43.566 \triangle E D U C A T I O N-$

$0.463 \Delta M I L I T A R Y-0.257 \Delta I N F R A S T R U C T U R E$.

Table 5: Cointegrating equation - Johansen normalization restriction imposed

\begin{tabular}{|c|c|c|c|c|c|}
\hline Beta & Coef. & Std. Err. & Z & $P>|z|$ & [95\% Conf. Interval \\
\hline \multicolumn{6}{|l|}{ _ce1 } \\
\hline GDPGROWTH & 1 & & . & . & \\
\hline HEALTH & 204.014 & 19.5454 & 10.44 & 0.000 & 165.7059242 .3225 \\
\hline EDUCATION & -43.566 & 7.8815 & -5.75 & 0.000 & $-58.4254 \quad-28.7063$ \\
\hline MILITARY & 0.4628 & 9.2474 & 0.05 & 0.960 & -17.661718 .58746 \\
\hline INFRASTRUCTURE & 0.2573 & 2.1497 & 1.12 & 0.905 & -3.955994 .47065 \\
\hline _cons & -9.8102 & & . & . & \\
\hline
\end{tabular}

In Table 5, the coefficients for health and education expenditure components are significant while coefficients for military and infrastructure expenditures are insignificant. 
The cointegrating equation (10) suggests that increased educational expenditures increases GDP growth whereas increased health expenses decreases GDP growth in the short run. Increase in educational expenses is an indicator of increase in human capital accumulation which is a key factor of production in the economy. Hence, increased productivity (through education) has a positive effect on GDP growth. On the other hand, increase in health expenditures has negative effects on GDP growth since good health is a prerequisite for development in the economy. These findings imply that, good health minus human capital development cannot grow the GDP of Kenya.

Looking at expenditures on infrastructure and military - there is negative relationship between GDP growth and these two public expenditure components. Public infrastructure such as roads are long-term capital projects which involves massive outflow of resources whose positive economic returns are not practically realized in the short-term. Therefore, in short-term, these expenses ideally have negative relationship with GDP growth since public resources are tied to these projects at initial stages whose economic value cannot be realized in the short-term. On the other hand, increased military expenditures has negative relationship with GDP growth since defense forces have no direct effect on the economy - they only have implied effects. Therefore, increased military expenses is a sign of increased insecurity which has a detrimental effect on economic growth in the short run.

The results for the individual adjustment of the variables in the short run towards the long run equilibrium are shown in Table 6 . The results shows that, GDP growth responds faster (at a speed of $3.6 \%$ ) than all public expenditures towards long run equilibrium if there is a disequilibrium in the economy in the short run. This is expected since GDP growth depends on other factors for it to increase hence should respond faster than variables which are independent from other factors such as public expenditures. For the expenditure components, education expenditure responds faster $(0.8 \%)$ than the rest of expenditure components with Infrastructure expenditures responding at the lowest speed of $0.2 \%$.

Table 6: Adjustment Parameters

\begin{tabular}{|c|c|c|c|c|c|}
\hline alpha & Coef. & Std. Err. & Z & $\mathrm{P}>|\mathrm{z}|$ & [95\% Conf. Interval] \\
\hline $\begin{array}{r}\text { D_GDPGROWTH } \\
\text { ce1 } \\
\text { L1. }\end{array}$ & -.0361502 & .0167293 & -2.16 & 0.031 & $\begin{array}{ll}-.068939 & -.0033614\end{array}$ \\
\hline $\begin{array}{c}\text { D_HEALTH } \\
\\
\text { L1. } 1 .\end{array}$ & -.0051555 & .0006538 & -7.89 & 0.000 & $\begin{array}{ll}-.0064369 & -.0038742\end{array}$ \\
\hline $\begin{array}{r}\text { D_EDUCATION } \\
\text { L1. } \\
\text { L1. }\end{array}$ & .0083117 & .002107 & 3.94 & 0.000 & $.0041821 \quad .0124413$ \\
\hline D_MILITARY & .0048515 & .0015275 & 3.18 & 0.001 & $\begin{array}{ll}.008577 & .0078452\end{array}$ \\
\hline $\begin{array}{r}\text { D_INFRASTRUCTURE } \\
\text { ce } 1 \\
\text { L1. }\end{array}$ & .0022133 & .0037083 & .60 & 0.551 & $-.0050548 \quad .0094815$ \\
\hline
\end{tabular}


Table 7: Langrange Multiplier Test

3.4 Post estimation analysis

\begin{tabular}{|c|c|}
\hline Eigenvalue & Modulus \\
\hline 1 & 1 \\
1 & 1 \\
1 & 1 \\
1 & 1 \\
$.01387463+.5971569 i$ & .597318 \\
$.01387465-.5971569 i$ & .597318 \\
$-.5397743+.2378406 i$ & .589851 \\
$-.5397743-.2378406 i$ & .589851 \\
$-.3096395+.09380319 i$ & .323536 \\
$-.3096395-.09380319 i$ & .323536 \\
\hline
\end{tabular}

The post estimation analysis of the model was performed to check for robustness of the model in modeling the relationship between GDP growth and public expenditures in Kenya. The autocorrelation in residuals in the VECM is checked using the Langrange Multiplier Test. The results are shown in Table 7.

HO: no autocorrelation at lag order

The results clearly indicate no serial correlation in the residuals and therefore the model was well specified in terms of the number of lags, and there is no finite-sample bias in the parameter estimates (Gonzalo, 1994). Next, the study checks the stability conditions of the specified VECM - to see if the number of cointegrating equations were correctly specified. Table 8 shows that the modulus of each eigenvalue is strictly less than one hence the estimated VECM is stable. Again, the graph of the eigenvalues in Figure 2 shows that none of the remaining eigenvalues appears close to the unit circle. The stability check does not indicate that the model is misspecified.

Table 8: Eigenvalue stability condition 


\begin{tabular}{|c|c|c|c|}
\hline lag & chi2 & df & Prob>chi2 \\
\hline 1 & 23.7595 & 25 & 0.53330 \\
\hline 2 & 19.5053 & 25 & 0.77227 \\
\hline 3 & 32.1557 & 25 & 0.15355 \\
\hline 4 & 29.4986 & 25 & 0.24361 \\
\hline
\end{tabular}

The VECM specification imposes 4 unit moduli.

Figure 2: Stability of Variance.

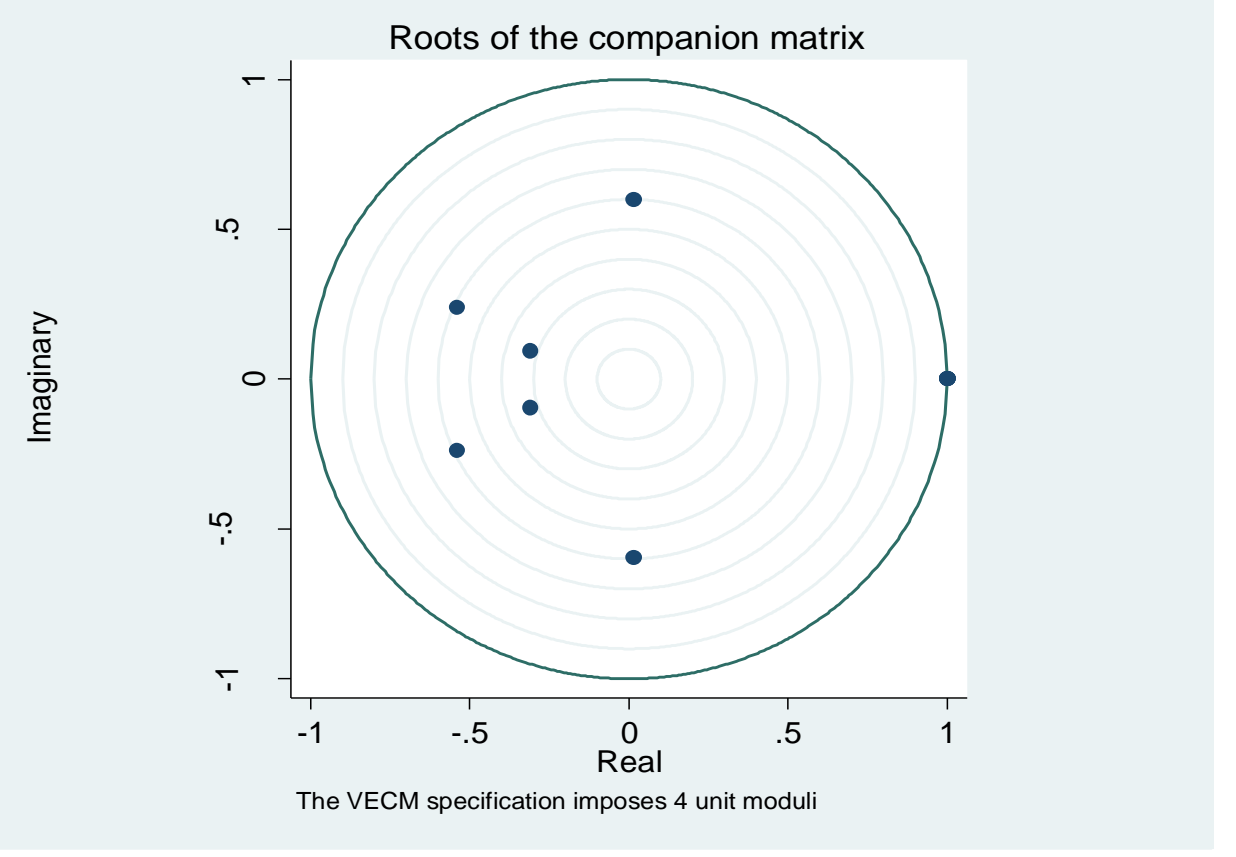

\subsection{Granger Casuality Tests}

Cointegration between two variables does not specify the direction of casuation between the variables. Economic theory suggests that there is at least one direction causation between variables(Fisher and Order, 1993). Estimation results for pair wise Granger Casuality between the variables are presented in Table 9.

Table 9: Granger Casuality Test 


\begin{tabular}{|l|c|c|l|}
\hline Null Hypothesis & $\chi^{2}$ & Probability & Decision \\
\hline GDP growth does not Granger cause HEALTH expenditures & 2.0744 & 0.150 & Do not reject \\
\hline GDP growth does not Granger cause EDUCATION expenditures & 2.7067 & 0.100 & Do not reject \\
\hline GDP growth does not Granger cause MILITARY expenditures & 1.4642 & 0.226 & Do not reject \\
\hline GDP growth does not Granger cause INFRASTRUCTURE expenditures & 1.8621 & 0.172 & Do not reject \\
\hline HEALTH expenditures does not Granger cause GDP growth & 0.2262 & 0.634 & Do not reject \\
\hline EDUCATION expenditures does not Granger cause GDP growth & 0.5637 & 0.453 & Do not reject \\
\hline MILITARY expenditures Granger cause GDP growth & 0.7231 & 0.395 & Do not reject \\
\hline INFRASTRUCTURE expenditures does not Granger cause GDP growth & 0.7231 & 0.639 & Do not reject \\
\hline EDUCATION expenditures does not Granger cause HEALTH expenses & 2.7587 & $0.097^{\star}$ & Reject \\
\hline HEALTH expenditures does not Granger cause EDUCATION expenses & 4.2768 & $0.039^{* *}$ & Reject \\
\hline MILITARY expenditures does not Granger cause HEALTH expenses & 6.2556 & $0.012^{* *}$ & Reject \\
\hline HEALTH expenditures does not Granger cause MILITARY expenses & 0.6605 & 0.416 & Do not reject \\
\hline
\end{tabular}

Where ${ }^{* *}$ mean significant at $5 \%$; and * mean significant at $10 \%$

The estimated results show that there is a unidirectional casuality running between health and education expenditures. It is found that health expenditures "Granger Cause" educational expenditures at $5 \%$ level of significance. Thus, any change in health expenditures will cause a change in educational expenditures. Further, there is a unidirectional casuality between military and health expenditures. These results imply that past values of military expenditures have a predictive ability in determining the present values of health expenditures - any change in military expenditures will cause a change in health expenses. The results suggests that there is switching expenditures between military and health - the public expenses on military can be switched to take care of health expenditures.

Overall, the results show that there is no causation between GDP growth and public expenditure components. These findings are consistent with those of Munge(2005) who finds no causal relationship between share of public expenditure and economic growth in Kenya. 


\subsection{Conclusion and Recommendations}

The purpose of this study is to primarily explain the relationship between economic growth and public expenditures in Kenya using a time series data collected between 1963 - 2012. The VECM was applied on the dataset and the results suggest that GDP growth has a positive significant relationship with education expenditures and a negative significant relationship with health expenditures. The relationship between GDP growth, and Infrastructure and Military expenditures are negative but insignificant in the short run. These findings suggest that economic growth depends heavily on human capital development in the economy, in the short run. Furthermore, the results show that short run fluctuations are adjusted towards a long run equilibrium at a speed of approximately $3.6 \%$. The speed is low implying weak co-movement between GDP growth and public expenditures towards a long run equilibrium.

Looking at causal relationships between GDP growth and public expenditure components, the study finds no causation between GDP growth and public expenditures in Kenya. However, there is a unidirectional causation running from health to education expenditures. In addition, the study finds that military expenditures Granger Cause health expenditures. An overarching conclusion from this study therefore is that the Government of Kenya (GoK) seem to switch expenditures between military and health. The government switches military expenditures to take care of health expenditures and not vice versa.

Since the public expenditures and economic growth co-move towards a long run equilibrium, the GoK should constitute strong monitoring and evaluation mechanisms to evaluate government financed projects in infrastructure, health and education sectors in order to have value for money spent on provision of public goods in the economy, and establish a higher equilibrium with economic growth. This study, however, applied the VECM as the main econometric model in explaining the relationship between GDP growth and public expenditures. For future studies, researchers should consider using a panel data to estimate the effect of public expenditures on economic growth.

\subsection{References}

Alexander, C. (2001). Market Models: A guide to financial data analysis. John Wiley \& Sons Limited.

Asari, F., and Baharuddin. N., \& Jusoh, N., \& Mohamad, Z., \& Shamsudin, N., \& Jusoff, Kamaruzaman. (2011). A Vector Error Correction Model (VECM) Approach in Explaining the Relationship Between Interest Rate and Inflation Towards Exchange Rate Volatility in Malaysia. World Applied Science Journal, 12, 49-56.

Baro, R., and Sala-i-Martin X (1992). Public Finance in Models of Economic Growth. Review of Economic Studies, 59, 645-661.

Dickey, D., and Fuller, W. (1979). Distribution of the estimators for autoregressive time series with a Unit Root. Journal of the American Statistical Association, 75(2), 427- 431.

Dimitrova, D. (2005). The Relationship between Exchange Rates and Stock Prices: Studied in a multivariate model. Issues in Political Economy, Vol (14).

Duasa, J. (2007). Malaysian Foreign Direct Investment and Growth: Does Stability Matter. Journal of Economic Cooperation, 28(2), 83-98.

Eastely, W. (2003). National Policies and Economic Growth: A Reappraisal. Working Paper No. 27, Center for Global Development, New York University.

Enders, W. (1995). Applied Econometric Time-Series. New York: John Wiley \& Sons Limited.

Fisher, L., and Order, D. (1993). Financial deregulation and dynamics of money, prices and output in New Zealand and Australia. Journal of Money, Credit and Banking, 25(2), 273-292. 
Gonzalo, J. (1994). Five alternative methods of estimating long-run equilibrium relationships. Journal of Econometrics, 60, 203-233.

Holmes, J., \& Hutton, P. (1990). On the Casual Relationship between Government Expenditures and National Income. The Review of Economics and Statistics, 72, 87-95.

Ivanov, Ventzila, Kilian and Lutz. (2005). A practitioner's guide to lag order selection for VAR impulse response analysis. Studies in Nonlinear Dynamics and Econometrics, 9(1).

Johansen, S. (1990). Statistical analysis of cointegration vectors. Journal of Economic Dynamics and Control, 12, 231-254.

Landau, L. (1986). Government and Economics Growth in the less Developed Countries An Empirical Study for 1960-1988. Economic Development and Cultural Change, 35, 35-75.

Maingi, J. (2010). The impact of government expenditure on economic growth 1963-2008. Unpublished Ph.D Thesis, Kenyatta University, Nairobi. Kenya.

Muthui, J., Kosimbei, G., Maingi, J., and Thuku, G. (2013). The Impact of Public Expenditure Components on Economic Growth in Kenya 1964-2011. International Journal of Business and Social Science, 4 233-252.

Ram, R. (1986). Government Size and Economic Growth: A New Framework and some evidence from cross-section and time series. American Economic Review, 76, 191-203.

Ram, R. (1987). Wagner's hypothesis in time-series and Cross-section Perspectives: Evidence from "real" data from 115 countries. The Review of Economics and Statistics, 69, 194-204.

Shioji, E.(2001). Public Capital and Economic Growth. Journal of Economic Growth, 6, 205 -277.

Singh, B., and Sahni, B. (1984). Causality between Public expenditure and National Income. The Review of Economics and Statistics, 66, 630-644.

Stiglitz, J. (2000). Economics of Public Sector. W. W. Norton and Company. 


\section{Appendix}

Figure 1: Time series Plots

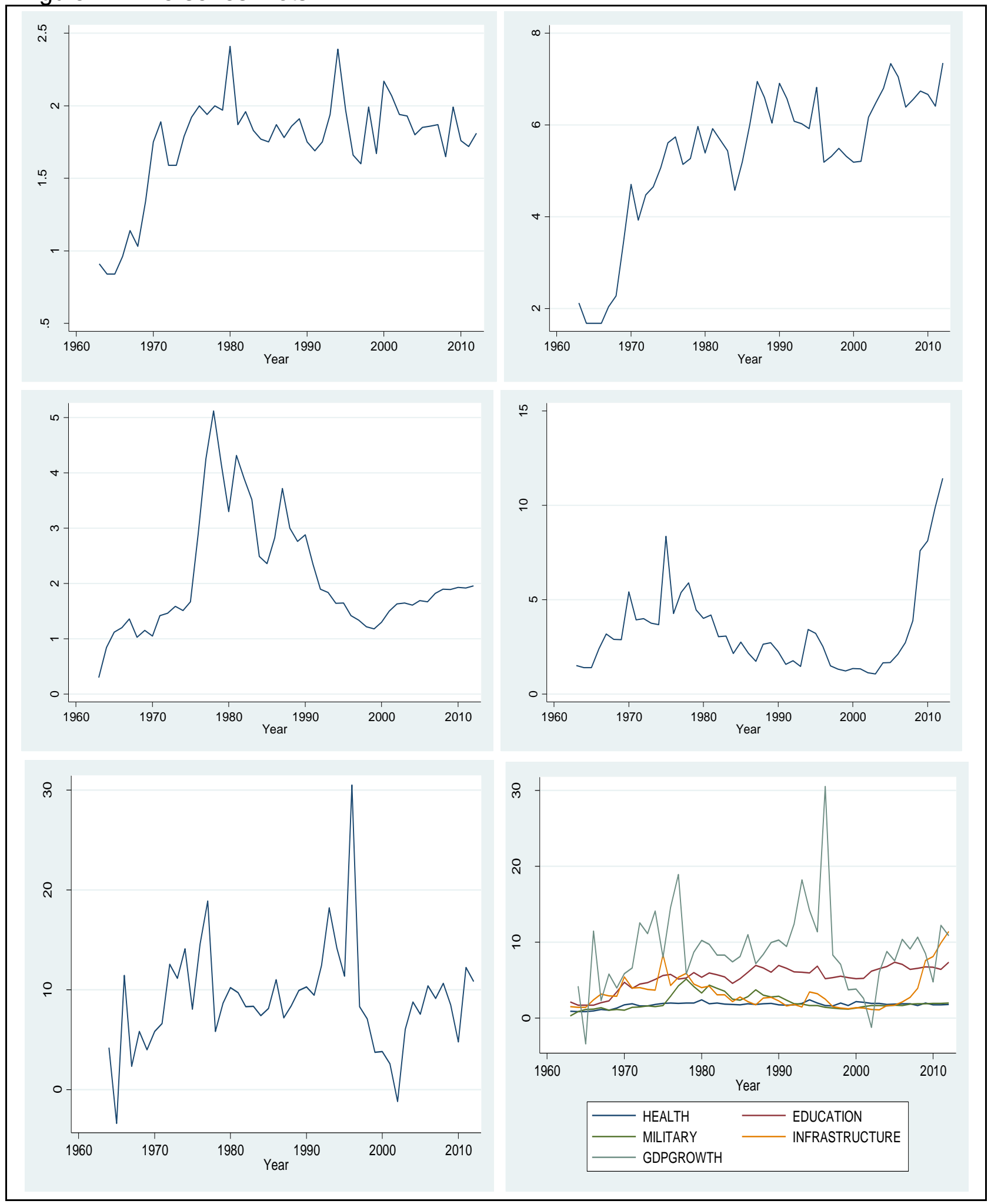

Source: Own adjusted based on the research data 


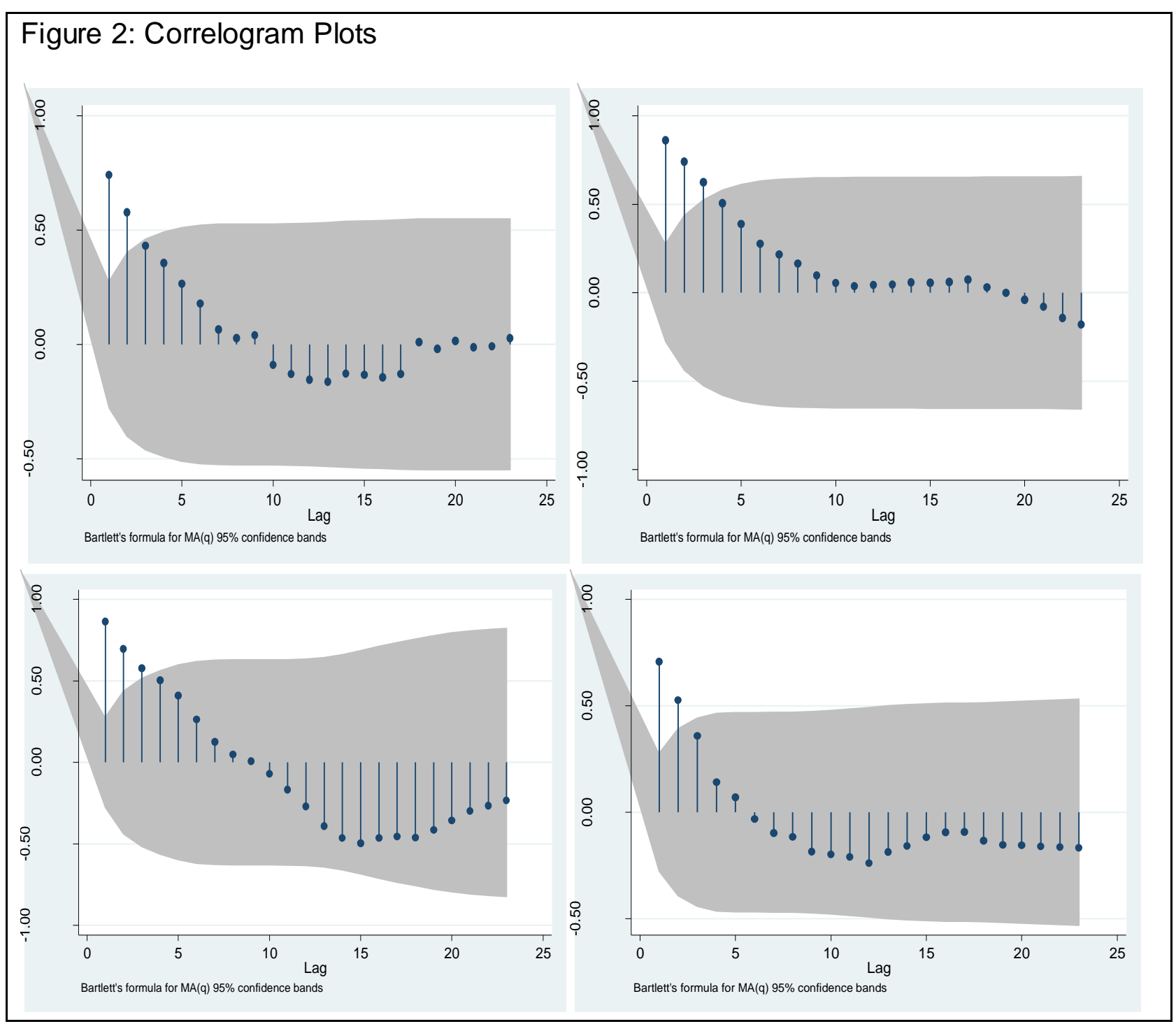

Source: Own adjusted based on the dataset 
Figure 3: Time Series Plots after Differencing
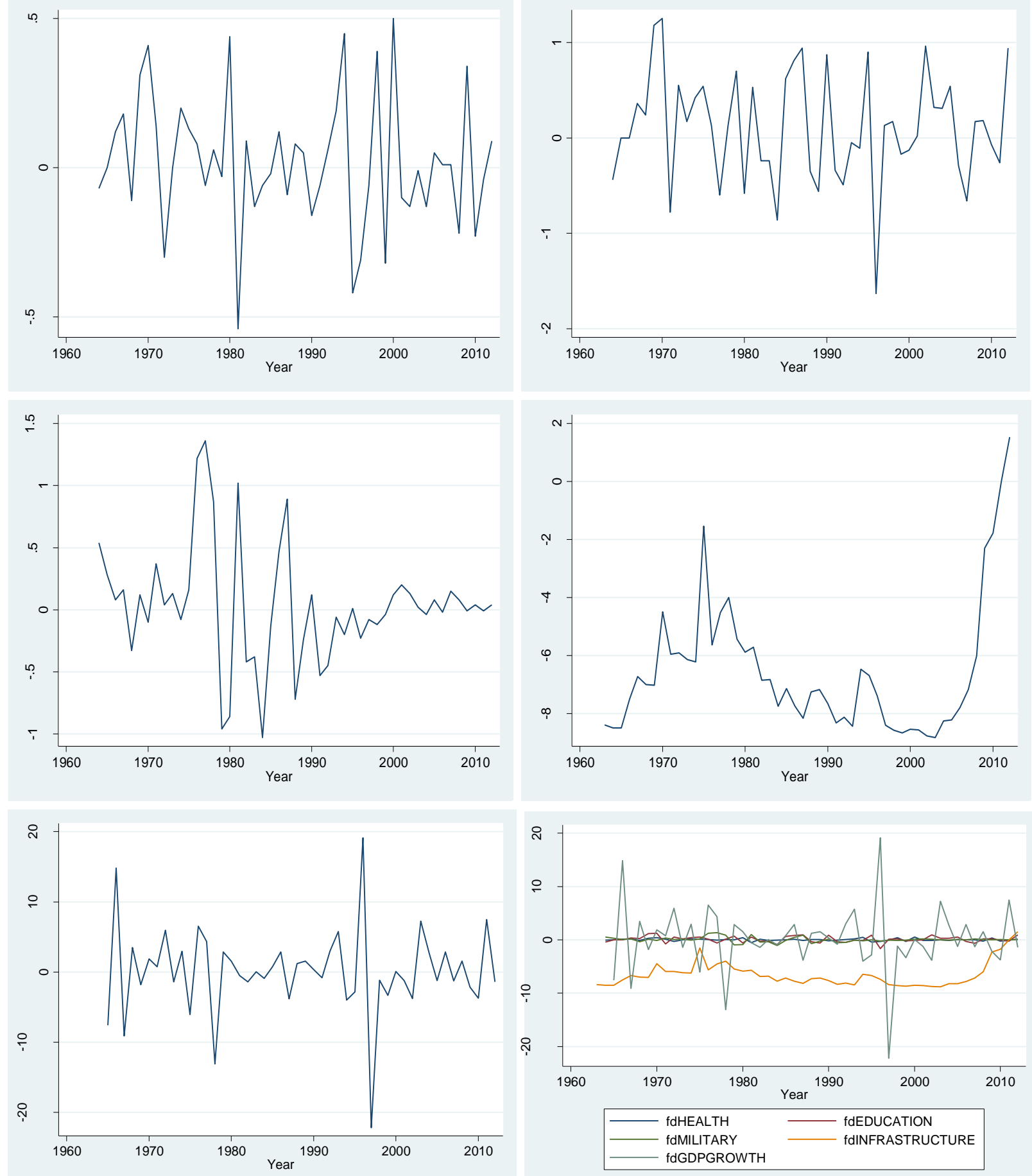

Source: Own adjusted from research data

Figure 4: Correlogram Plots after First Difference ${ }^{5}$

${ }^{5}$ The plots show stationarity after first difference 


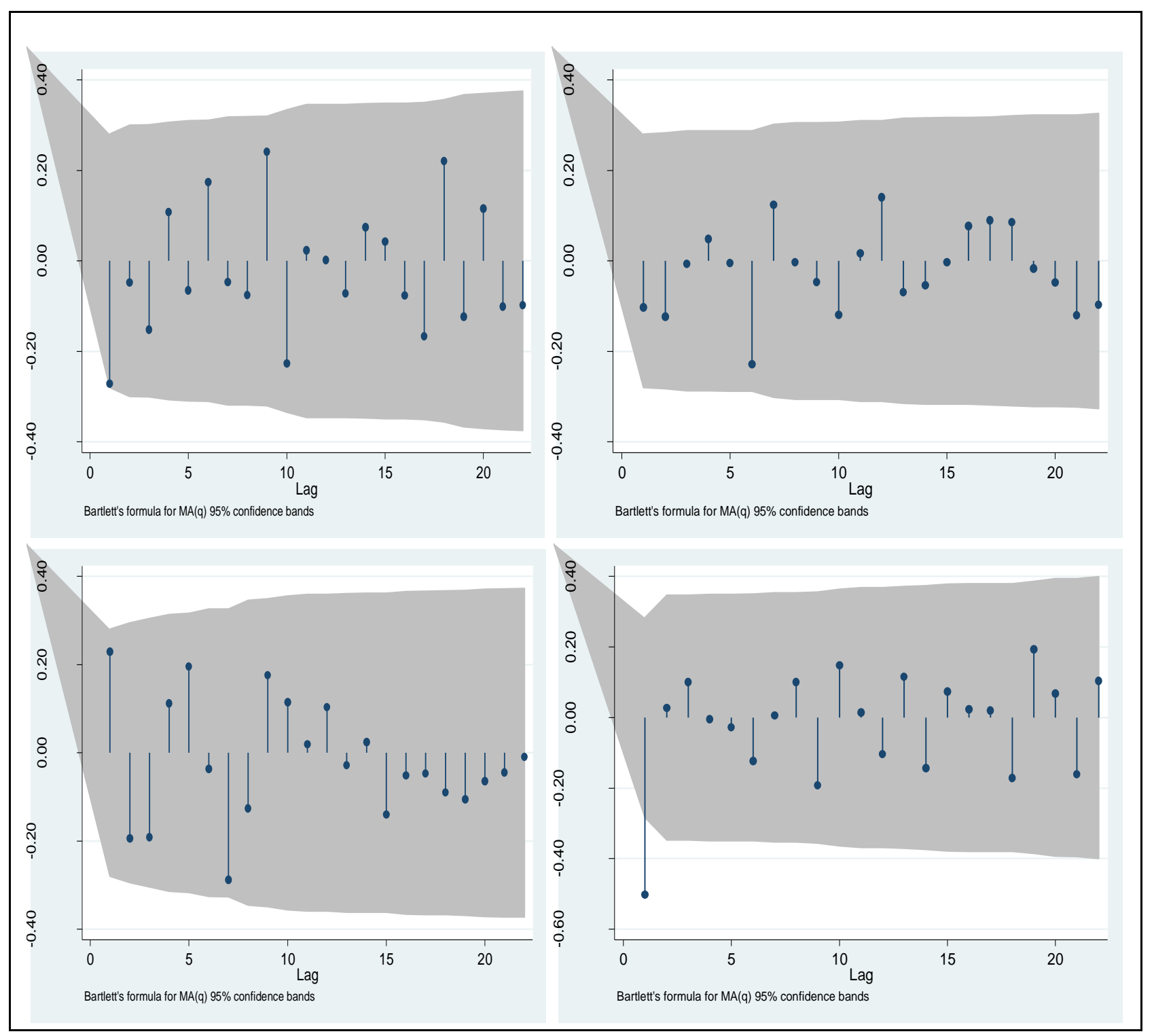

